Dossiê: Desafios teológicos do Pluralismo Religioso - Artigo original (c) $\underset{\mathrm{EY}}{(\mathbf{B}}$

\title{
Protestantismo liberal, ecumênico, revolucionário e pluralista no Brasil - um projeto que ainda não se extinguiu.
}

\author{
Liberal, ecumenical, revolutionary and pluralistic Protestantism in Brazil - \\ a project that has not been extinguished as yet
}

Carlos Eduardo B. Calvani*

\begin{abstract}
Resumo
As igrejas protestantes do Brasil, nos últimos anos, tornaram-se mais intolerantes ao pluralismo, avessas ao ecumenismo e imunes à autocrítica teológica. O perfil da atual liderança das igrejas protestantes brasileiras em nada se assemelha à geração de intelectuais protestantes dos anos 30 a 50 e menos ainda à geração dos protestantes ecumênicos e revolucionários dos 60 e 70. Essas duas gerações, dentro de seus limites e possibilidades, ajudaram a construir no Brasil um tipo de protestantismo que, embora minoritário, trouxe muitas contribuições, não somente às suas igrejas, mas à sociedade. Porém, esse tipo de protestantismo parece estar desaparecendo nas ondas de um modelo conservador, pouco afeito à reflexão teológica e desinteressado nas novas demandas de inclusão social e nos direitos das minorias. Aparentemente, vivemos o fim de um tipo de protestantismo no Brasil. Aquele protestantismo temperado pelos ideais da modernidade parece ter fracassado. O texto recupera um pouco da memória dessas duas gerações, valorizando sua oposição aos avanços fundamentalistas que encontraram solo fértil no Brasil e presta homenagem aos heróis da resistência, partilhando dos mesmos ideais e da mesma esperança: que o protestantismo brasileiro seja mais liberal, ecumênico, revolucionário e pluralista.
\end{abstract}

Palavras-chave: Protestantismo brasileiro; ecumenismo. Igreja e sociedade. Teologia protestante; fundamentalismo.

\begin{abstract}
In recent years, Protestant churches in Brazil have become intolerant to pluralism, opposed to ecumenism and immune to theological criticism. The profile of the current leadership of Brazilian Protestant churches in no way resembles the generation of Protestant intellectuals from the 30 's to the 50 's and even less the generation of ecumenical and revolutionary Protestants of the 60's and 70's. These two generations, within their limits and possibilities, helped build in Brazil a kind of Protestantism that, in spite of being a minority group, brought many contributions not only to their churches, but also to society. However, this type of Protestantism seems to be disappearing in the waves of a conservative model, not much given to theological reflection and uninterested in the new demands of social inclusion and in the rights of minorities. Apparently, we experience the end of this type of Protestantism in Brazil. That Protestantism tempered by the ideals of modernity seems to have failed. The text recovers some memories of these two generations, highlighting their opposition to fundamentalist advances that have found fertile ground in Brazil, and pays tribute to the heroes of resistance, sharing the same ideals and the same hope: may the Brazilian Protestantism be more liberal, ecumenical and pluralistic.
\end{abstract}

Keywords: Brazilian Protestantism; Ecumenism; Church and society; Protestant theology; Fundamentalism.

Aos heróis da resistência

Artigo recebido em 27 de julho de 2015 e aprovado em 07 de dezembro de 2015.

* Doutor em Ciências da Religião pela Universidade Metodista de São Paulo e professor no Programa de Pós-Graduação em Ciências da Religião da Universidade Federal de Sergipe (UFS). Páis de origem: Brasil. E mail: cecalvani@hotmail.com

Horizonte, Belo Horizonte, v. 13, n. 40, p. 1896-1929, out./dez. 2015 - ISSN 2175-5841 


\section{Introdução}

A gente se cansou de viver um cotidiano bastante dificil. Às vezes fico pensando e fazendo analogia com o verso do Bandeira: "A vida toda poderia ter sido e não foi". Daí eu penso: "Uma Igreja que poderia ter sido e não foi"

(Waldo César, sociólogo protestante, in CÉSAR, 2014, p. 98).

As igrejas protestantes tradicionais ${ }^{1}$ no Brasil estão se tornando cada vez mais intolerantes ao pluralismo, avessas ao ecumenismo, simpatizantes de movimentos sociais reacionários e imunes à autocrítica teológica. Os termos "protestante" ou "evangélico" estão desacreditados, associados a pastores televisivos endinheirados, indústria gospel, denúncias de desvios financeiros, exploração da religiosidade popular, políticos ultradireitistas com tendências teocráticas e discursos que inspiram e alimentam a violência contra as religiões afro-brasileiras e as pessoas homoafetivas. Para as novas gerações protestantes, a palavra missão significa apenas um conjunto de estratégias em prol do crescimento de igrejas e a eliminação de concorrentes. As ações assistencialistas são justificadas como cosméticos necessários ao proselitismo. A antiga sobriedade litúrgica foi substituída, mesmo nas igrejas tradicionais, por reuniões que favorecem o emocionalismo e por um modelo de homilia midiática, com pregadores circulando pelo templo como animadores de auditório.

Onde estão os protestantes que, inspirados pelos teólogos liberais ou pelo sonho motivador da criação do Conselho Mundial de Igrejas (CMI), ajudaram a construir a história do movimento ecumênico no Brasil e dedicaram seu tempo e seus melhores talentos à formulação de uma teologia que dialogava com as ciências e pretendia engajar as igrejas em uma prática social transformadora? Onde estão os herdeiros daqueles protestantes que, mesmo à custa de perseguições

\footnotetext{
${ }^{1}$ Neste artigo, a expressão "igrejas protestantes tradicionais" delimita um campo específico: o conjunto de igrejas organizadas entre os séculos XVI e XVIII, tendo por base os princípios teológicos da Reforma e seus desdobramentos no contexto norte-americano. Mais especificamente, referimo-nos às Igrejas Presbiterianas, Metodistas, Batistas, Congregacionais, Luteranas e Episcopais-anglicanas, que chegaram ao Brasil ainda no século XIX.
} 
eclesiásticas e extraeclesiásticas, vislumbraram a possibilidade de mobilizar as igrejas para uma ação social inculturada e libertadora? Onde estão os herdeiros daqueles que incorporaram o termo "revolução" aos seus discursos e escritos ou daqueles que, nas reuniões do ISAL (Igreja e Sociedade na América Latina), descobriram que há causas mais nobres pelas quais lutar, para muito além do mero discurso de crescimento e expansão das igrejas? Onde estão aqueles que tomariam o bastão repassado pela geração anterior e dariam continuidade ao sonho de um protestantismo aberto à pluralidade, atento às causas políticas e sociais e receptivo às manifestações estéticas da cultura brasileira?

Essas perguntas não são tão novas. Elas apenas são escritas em outra época. Em 1970, Rubem Alves já se perguntava: "há algum futuro para o protestantismo na América Latina?” (ALVES, 1982. p. 130) e, no início dos anos 80, a mesma pergunta continuava a ser formulada de outro modo pelo mesmo autor:

Que ocorreu com a geração que convulsionou as igrejas nos anos 1950? Esta é uma pesquisa que está por ser feita. Um grande número, simplesmente, abandonou as igrejas. Outros se ligaram a congregações mais liberais, desenvolvendo aí as atividades dos crentes comuns, sem voos mais ousados. Alguns se ajustaram, sob as pressões institucionais a que já nos referimos. Outro grupo, por fim, tratou de criar espaços alternativos, ecumênicos e de certa forma paraeclesiásticos, como instrumentos de seus ideais (ALVES, 1982, p. 169).

Antes de Alves, Tillich fizera a mesma pergunta em 1937, no artigo "Protestantism in the Present World-Situation", republicado com o título "The End of the Protestant Era?” (TILLICH, 1948/1992). O teólogo alemão, na época, sentia-se incomodado com os rumos do protestantismo na Alemanha hitlerista que o exilara, especialmente com o enfraquecimento do poder profético, o individualismo exacerbado, o desprezo por causas sociais e a falta de compromisso para com o proletariado. Ao mesmo tempo, assustava-se com o avanço do fundamentalismo no perfil do protestantismo norte-americano. Daí a escolha de um título acompanhado por um ponto de interrogação, e o desenvolvimento de um texto recheado de dúvidas - "estaríamos no fim da era protestante?”. 
Aparentemente, também estamos vivendo o caso desse tipo de protestantismo no Brasil. A visibilidade do estereótipo descrito no primeiro parágrafo levou muitos que rejeitam tal modelo a afastarem-se de suas igrejas de origem, muitas delas agora aos cuidados de lideranças descomprometidas com causas sociais, com a defesa dos oprimidos e mesmo com o estudo da teologia. Alguns migraram para o mundo acadêmico e outros retomaram antigos projetos profissionais. Não necessariamente abandonaram a filiação às suas igrejas de origem, mas mantêm com elas uma relação institucional tênue e esporádica, sustentada muito mais por relacionamentos fraternos construídos em outros tempos. Compreensivelmente, já não veem muito sentido em frequentá-las. Sentem-se como Sísifo, arrastando uma imensa pedra em um penhasco, que sempre despenca tão logo o topo se aproxima.

O perfil da atual liderança das igrejas protestantes brasileiras pouco se assemelha ao da geração dos anos 30 a 50 do século XX e menos ainda ao da geração dos anos 60 e 70 . Aquele protestantismo temperado por ideais da modernidade parece ter fracassado. Foi substituído por um protestantismo popular e popularesco que se subdivide em feudos e capitanias hereditárias, reproduzindo os padrões do coronelismo e caudilhismo latino-americanos.

O presente texto busca pistas para compreender esse tipo de protestantismo que parece dar seus últimos suspiros, a partir do resgate de personagens que, no passado, ajudaram a construir esse modelo. Em um segundo momento, percorre algumas referências históricas que nos ajudam a compreender as causas do enfraquecimento do protestantismo pluralista, ecumênico, revolucionário e liberal no Brasil, fragilizados pela progressiva solidificação do fundamentalismo, das agências paraeclesiásticas e de movimentos neo-evangélicos (ou "evangelicais") que corroeram o protestantismo brasileiro em três áreas: o ecumenismo, a educação teológica e a ação social. 


\section{Protestantes intelectualizados e liberais - a geração da "Cultura Religiosa"}

O protestantismo, como se sabe, nunca foi homogêneo. Desde o século XVI, esse termo é um conceito genérico que abriga diferentes modelos de organização eclesiástica, de relação com a sociedade (desde os anabatistas radicais até as igrejas protestantes estatais) e de enorme elasticidade teológica. Fundamentalistas como Carl McIntire e Francis Schaeffer, escritores pentecostais como Benny Hinn e Kenneth Hagin, ou liberais como John Spong, todos são, teoricamente, protestantes. Se há algum sentido ainda nesse termo, ele simplesmente significa "cristianismo ocidental não católico romano".

Acostumamo-nos a imaginar, a partir de uma determinada literatura acadêmica, que o protestantismo é um monobloco com poucos contornos diferenciais, formado por cristãos devotados a uma ética do trabalho e do progresso, aberto às ciências e tolerante para com a pluralidade religiosa e cultural. Esse padrão, porém, só se aplica a um tipo de protestantismo e, talvez, somente a uma época. Ricardo Mariano questionou o viés weberiano de muitos estudiosos do protestantismo brasileiro que o identificam como um agente modernizante, e afirmou, com certo exagero, que o protestantismo descrito por Weber nem sequer aportou no Brasil (MARIANO 1999, p. 94). Às vezes esquecemo-nos que "A ética protestante e o espírito do capitalismo" é um estudo também datado, que desdobra as consequências da matriz ética da reforma em um tipo de protestantismo majoritário na Europa e que ainda tinha muito fôlego no tempo de Weber. Esse modelo também está em declínio por lá, esfrangalhando-se diante do crescimento de grupos evangélicos carismáticos, conforme recente observação de Peter Berger (2015). Na Alemanha, esse tipo de protestantismo foi chamado de "Kulturprotestantismus" (NIEBUHR, 1967, p.111)2. Na Inglaterra vitoriana, esse modelo dominou a liderança da Church of England através do lema "A Igreja

\footnotetext{
${ }^{2}$ Richard Niebuhr (1967), em uma nota de rodapé de seu livro Cristo e Cultura, erroneamente atribui a Barth a criação desse termo, associado a teólogos como Ritschl, Harnack e Troeltsch. Porém, o termo já era conhecido desde 1860 na Alemanha, tendo seu auge na década de 1900 e caindo em desuso após a guerra de 1914-1918. Seu eixo era o conceito de Reino de Deus, compreendido como inspiração de valores éticos, educacionais e espirituais associados à modernidade na modelagem de uma civilização protestante europeia.
} 
Anglicana é o Estado em oração e devoção a Deus”, o que garantia a presença de clérigos nas colônias e o financiamento estatal à construção de templos e escolas. Nos Estados Unidos, preponderou nas igrejas do norte e nordeste, em contraste com o conservadorismo do sul, no qual vicejou outro tipo de protestantismo, que se tornou a matriz do fundamentalismo teológico.

Cândido P. Camargo, ainda nos anos 70, observou que o protestantismo apresentou duas faces no Brasil - uma delas alinhava-se com os ideais de progresso científico da modernidade e investia no potencial transformador da educação; a outra face, mais conservadora e de matriz rural, apenas buscava um lugar ao sol, adaptando as novas crenças a estruturas herdadas do Brasil colonial (CAMARGO, 1973). Os missionários que vieram dos Estados Unidos para o Brasil no século XIX estavam divididos entre esses dois modelos. A maioria veio do sul dos Estados Unidos (alguns, inclusive, escravocratas desencantados com a derrota na Guerra da Secessão e a libertação de seus escravos); um número menor veio da região norte, convictos de que seu modelo garantiria progresso e o ingresso da América Latina na modernidade. Para esses, a palavra "missão" envolvia não apenas a pregação conversionista, mas também o investimento em educação, o incentivo à filantropia e o fomento à cultura e às artes. A partir da criação do Mackenzie College em São Paulo (1870), diversas escolas foram organizadas nos centros urbanos e algumas em regiões rurais, a fim de garantir a adequação da sociedade brasileira nos trilhos da modernidade, e algumas se tornaram importantes universidades.

O problema era que esse modelo de missão e de relacionamento com a sociedade não garantia às comunidades lideradas por esses missionários, crescimento numérico na mesma proporção das comunidades aos cuidados do grupo mais conservador. Afinal, protestantes formados nesse modelo sempre foram mais comedidos e evitavam conflitos abertos com as lideranças católicas. Preferiam, antes, os sermões quase parnasianos, cuidadosamente elaborados segundo regras de oratória clássica, com citações de Cícero, Homero, Camões e 
outras obras de literatura, proclamados em reuniões reverentes nas quais a nova fé era apresentada como depurada de superstições e aberta ao progresso, incentivadora da educação, da moderação e da sobriedade.

Não por acaso, esse tipo de protestantismo alçou algum prestígio entre a classe média dos centros urbanos brasileiros do início do século XX. A arquitetura dos templos dessa época permanece ainda hoje como símbolo desse tipo de protestantismo, com suas torres, órgãos de tubo e galerias para o coral, diametralmente opostas aos palcos e ao minimalismo estético dos atuais salões de culto evangélicos. No interior do Brasil, porém, a expansão protestante apenas esboçou esse modelo. Mendonça (1984) demonstrou que a implantação do protestantismo no interior acompanhou os trilhos ferroviários e a economia do café, mantendo sempre certas reservas e desconfianças para com os processos de industrialização nos centros urbanos.

Fatores dessa natureza talvez ajudem a compreender por que foi exatamente em centros urbanos como São Paulo que despontou uma geração de protestantes que angariou respeito nos meios acadêmicos da época. Muitos se dedicaram à literatura - a Gramática Expositiva de Eduardo Carlos Pereira, pastor da Igreja Presbiteriana Independente do Brasil, foi utilizada nas escolas brasileiras entre 1907 e 1957 em sucessivas reimpressões. Éber Ferreira Lima (2009), em sua tese sobre os intelectuais protestantes brasileiros e a produção da cultura entre 1903 e 1942, recupera muitos detalhes dessa história, destacando, além de Pereira, outros nomes como Vicente Themudo Lessa (historiador), Adolph Hempel (entomólogo), Frederico Hohene (botânico), Flamínio Fávero (primeiro diretor da Faculdade de Medicina em São Paulo), Othoniel Motta (filólogo), Theodoro Henrique Maurer Júnior, Isaac Nicolau Salum (linguistas), Erasmo Braga e Miguel Rizzo Júnior, dentre outros. Todos eram pastores ou líderes leigos presbiterianos e metodistas - comprometidos com as dinâmicas internas de suas igrejas e também com o mundo acadêmico. A frase do reverendo Othoniel Motta, "tem de haver um ajuste entre a sacristia e o laboratório, de maneira que possam viver lado a lado como bons amigos" (MOTTA, 1945, p. 118) representa, para Lima, a síntese do 
pensamento desses protestantes e, por isso, o historiador o considera "inspirador e patrono do grupo intelectual protestante (...), modelo de cristão protestante moderno e esclarecido" (LIMA, 2009, p. 15). Um parágrafo mais longo da tese de Lima merece ser citado na íntegra:

Os intelectuais protestantes brasileiros, já distantes temporalmente da doutrinação inicial dos missionários norte-americanos do século XIX, estavam voltados culturalmente para a Europa. Isso se devia, em grande medida, ao seu envolvimento com outros ramos do conhecimento, como a filosofia, a filologia, a literatura e os estudos sociológicos. Nesses respectivos campos do conhecimento humano, tais intelectuais protestantes integravam-se àqueles que olhavam com respeito $\mathrm{e}$ admiração para a ciência humanística europeia, em oposição ao pragmatismo norteamericano. De posse dessa bagagem, procuraram injetar em sua Igreja o antídoto contra o preconceito científico e o conservadorismo teológico, ao longo das décadas de 20, 30 e 40 do século XX. Foram, por causa disso, duramente combatidos dentro de seu próprio reduto religioso, face à mentalidade existente e já consolidada. No entanto, constituíram-se na reserva de modernidade que permitiu a esse ramo do protestantismo adequar-se à sociedade urbana brasileira (particularmente a paulista), nos anos da ditadura Vargas e no período imediatamente subseqüente à Segunda Guerra Mundial. Pode-se dizer que ajudaram a construir uma identidade cultural protestante que valoriza os saberes modernos, particularmente entre seus líderes, o que a diferencia da identidade assumida pelas igrejas declaradamente fundamentalistas. (LIMA, 2009, p. 11).

Essa geração produziu uma literatura que ajudou a formar novas lideranças, particularmente de jovens protestantes ligados à UCEB (União Cristã de Estudantes Brasileiros) e que, nos anos posteriores, envolver-se-iam no movimento ecumênico, em causas sociais ou na Teologia da Libertação. Lima chama essa literatura de "produção de sacristia", por ser destinada aos processos educativos internos das igrejas. As publicações Revista de Cultura Religiosa (19211926), Lucerna (1929 e 1930), Fé e Vida (1939-1945) e Unitas (1945-1963), abordavam temas científicos, sociais e culturais, visando "habilitar os protestantes brasileiros ao diálogo inteligente com o que seus dirigentes chamavam de 'classes cultas' brasileiras" (LIMA, 2009, p. 89). Boa parte dessa literatura ainda pode ser encontrada nas bibliotecas de Seminários Teológicos mais antigos ou no Centro de Documentação e História Rev. Vicente Themudo Lessa, da $1^{\text {a }}$ Igreja Presbiteriana 
Independente de São Paulo à espera de um projeto que as digitalize com vistas à socialização do conhecimento.

Além disso, essa geração ajudou a criar uma consciência ecumênica extremamente salutar para os limites do protestantismo brasileiro da época. Eduardo C. Pereira, Álvaro Reis e Erasmo Braga participaram do Congresso do Panamá (1916) e Braga presidiu o Congresso seguinte em Montevidéu (1925), eventos que procuravam congregar as igrejas protestantes em torno de ideais de ação comum. Braga foi membro de instituições como o Clube Positivista, o Centro de Ciências de Campinas, a Academia de Letras de São Paulo, a maçonaria e o Rotary Club (GONÇALVES, 2013; MATOS, 2008) e o primeiro crítico do sectarismo, do divisionismo protestante e dos modelos implantados por missionários norte-americanos (FERREIRA, 1975). Defendia, antes, uma maior aproximação com o protestantismo francês, fortemente influenciado pelo Iluminismo (BRITO, 282).

Nessa época, os protestantes europeus ligados aos Movimentos Vida e Ação, Fé e Ordem e ao Conselho Missionário Internacional gestavam o embrião do futuro CMI (Conselho Mundial de Igrejas). No Brasil, as igrejas protestantes uniram esforços em 1934 e criaram a Confederação Evangélica do Brasil (CEB), com inspiração ecumênica e preocupação social. Na América Latina, jovens argentinos, uruguaios e chilenos fundaram a ULAJE (União Latino-Americana de Juventudes Evangélicas) em 1941, organismo voltado à formação da juventude e à "condenação do atual sistema capitalista baseado na opressão e desigualdade econômica" (ULAJE, 1942). A história da ULAJE até seu esvaziamento e declínio também merece ser resgatada, pois é desse grupo de jovens que emergiriam futuras lideranças ligadas aos movimentos sociais e à Teologia da Libertação.

Muitos protestantes dessa geração, como Miguel Rizzo Júnior, Othoniel Motta, Erasmo Braga, Epaminondas Melo do Amaral e, um pouco mais tarde, Jorge Bertolaso Stella, receberam o rótulo de "liberais" ou "modernistas", atribuído por seus opositores. Porém, esse adjetivo na época não tinha ainda o tom 
pejorativo que ganhou a partir dos anos cinquenta. Soava como um elogio, garantia certo status e não prejudicava suas atuações eclesiásticas. Rizzo, Motta e Amaral eram ávidos leitores da revista francesa La Revue du Christianisme Social, lançada em 1887 pelo pastor Gédéon Chastand, da Igreja Reformada. Chastand era ligado ao movimento do cristianismo social defendido pelo anglicano Frederick Denison Maurice (MARASCHIN, 1991) e que, nos Estados Unidos, ficou conhecido como "evangelho social”, associado ao nome de Walter Rauschenbusch, um dos teólogos mais citados por Rubem Alves em seus primeiros escritos. Tillich também foi colaborador desse movimento na Alemanha, defendendo-o em diversos artigos e, sobretudo, no livro "A decisão socialista”, de 1933. A revista francesa marcou época como representante do liberalismo protestante na França e dentre seus colaboradores estava Suzanne de Dietrich (uma das entusiastas do processo de organização do CMI). Éber Ferreira Lima lembra que “o jovem Roger Bastide, com apenas 23 anos, teve seu primeiro artigo publicado exatamente em LRCS de maiojunho de 1921" (LIMA, 2009, p. 93). A aproximação com teólogos mais interessados nas responsabilidades sociais das igrejas para com a sociedade, inevitavelmente abriu espaço para o trio Rizzo-Motta-Amaral ser considerado "modernista e liberal". Esse "liberalismo", porém, não se pretendia herético ou agressivo, esforçando-se, antes, por um aprofundamento hermenêutico ousado para a época, além de defender o direito de divergir, educada e polidamente, de certas ênfases pontuais. A partir dos anos 50, em virtude da penetração do fundamentalismo no Brasil, os adjetivos "liberal" ou "modernista" foram associados à palavra "heresia”, e passaram a representar perigosas ameaças à estrutura e organicidade das igrejas protestantes. A atuação dessa geração de protestantes está nos bastidores de uma cisão ocorrida na Igreja Presbiteriana Independente do Brasil (IPI) em 1940, que resultou na organização de duas denominações menores - a Igreja Presbiteriana Conservadora e a Igreja Cristã de São Paulo (que reunia os chamados "liberais"). 
Jorge Bertolaso Stella não fazia parte desse grupo, por ser ainda muito jovem na época. Porém, sua história merece ser resgatada em um trabalho de maior fôlego. Nascido na Itália em 1888, veio para o Brasil quando tinha três anos de idade, com seus familiares imigrantes. Foi carroceiro em Mogi-Mirim e nunca frequentou qualquer escola formal. Autodidata, ainda era semianalfabeto quando, aos 23 anos, mudou-se para São Paulo a fim de estudar no Colégio Evangélico fundado por Eduardo Carlos Pereira. Interessou-se pelas religiões orientais, especialmente o hinduísmo, e se correspondia com eminentes intelectuais da Escola Italiana de História das Religiões. Pastoreou várias igrejas da região de Sorocaba e, em 1933, foi eleito pastor-titular da $1^{\text {a }}$ IPI de São Paulo, exercendo o cargo até 1958 e permanecendo como pastor-emérito até sua morte em 1980. Bertolazzo foi o responsável pela primeira tradução do Bhagavad-Gita para o português. É de sua autoria também a primeira gramática Sânscrito-Português com glossário, adotada como material didático da Universidade de São Paulo por muitos anos. Apaixonado pela História das Religiões Comparadas, publicou diversos livros pela Imprensa Metodista ou pela própria $1^{\text {a }}$ IPI, com pesquisas sobre mística, os manuscritos do Mar Morto, religiões orientais, religiões préhistóricas, etc., utilizando largamente a fenomenologia comparativa sem nunca emitir qualquer juízo negativo sobre qualquer outra religião.

Bertolaso Stella é, certamente, um dos pioneiros do que hoje chamamos "Ciências da Religião" no Brasil. Membro do Instituto Histórico e Geográfico de São Paulo e constantemente requisitado para palestras na USP, foi um dos primeiros colaboradores da Revista de História da USP, onde publicou "A morte de Pericle Ducati e a etruscologia" (1950) e uma resenha de "L'Afrique Poliglotte", livro de Oddone Assirelli, que atraiu os olhares acadêmicos para o estudo das línguas e religiões africanas. Professor de História das Religiões do antigo Seminário Teológico da IPI, denunciava, do púlpito da $1^{\text {a }}$ IPI de São Paulo, qualquer proselitismo como uma falha de caráter do cristianismo protestante, e defendia que o hinduísmo tinha muito a ensinar ao mundo ocidental. Por isso, além da tradução do Bhagavad-Gita, escreveu também "O Rig-Veda" (1958), “A 
oração na história das religiões" (1968), “As religiões da Índia” (1971), "Estudos Hindus" (1978), dentre outros. Na qualidade de pastor, defendia que "todas as religiões gozam de uma inspiração verdadeira. Cada uma de suas Bíblias ocupa seu lugar em um grau determinante na escala das revelações divinas" (STELLA, 1957/1981, p. 24), que '”Buda, Zoroastro, Moisés, Maomé e Cristo são intérpretes de Deus" (STELLA, 1979, p. 17), que "não existe o pecado [...] Deus não envia ninguém para o inferno ou para a perdição, porque não existem nem inferno e nem diabo. Todas as criaturas se salvam, para usar a linguagem teológica" (STELLA, 1976, p. 21). Mesclando teologia, história das religiões e fenomenologia, ensinava: "Eu sou monoteísta. Mas num outro sentido, os deuses são tantos quantos crêem em Deus e repito, eu também tenho o meu Deus diferente dos outros que crêem no seu Deus. O meu Deus, por exemplo, não condena ninguém. Para mim, Deus não criou Satanás, o diabo, nem o inferno" (STELLA, 1957/1981. p. 35). Além disso, em pleno regime militar, apregoava do púlpito e depois publicava em seus livros frases como "a natureza é comunista e altruísta. Deus é comunista. Ele criou tudo para todos. A criança nasce comunista" (STELLA, 1976, p. 23-24). Liberal, pluralista, protestante!

Os primeiros herdeiros dessa geração atuaram ativamente na UCEB (União Cristã dos Estudantes do Brasil), organizada em 1940. Seu primeiro secretário geral foi o reverendo Jorge César Mota. Em uma época na qual a comunicação era mais lenta, estabeleceram vínculos com outros protestantes latino-americanos por meio da ULAJE. A $1^{\text {a }}$ Conferência Latino-americana organizada pela UCEB foi realizada em 1952 em São Paulo, com o tema "A vocação cristã", e teve como principal conferencista um jovem missionário presbiteriano recém-expulso da Colômbia, chamado Richard Shaull. Jovelino Pereira Ramos era um dos entusiasmados jovens formados nessa geração. Mais tarde exilado pelo governo militar, Ramos deu o seguinte depoimento a respeito da importância da UCEB e de Shaull: 
A área de atuação do Shaull que mais me cativou foi o trabalho com a União Cristã de Estudantes do Brasil. Na segunda parte da década de 1950 e durante toda a década de 1960 os estudantes eram um dos setores mais dinâmicos da vida política do Brasil. A UCEB estava inserida naquela dinâmica. Como tal, ela organizava e provia um ambiente de apoio aos jovens acadêmicos de procedência protestante. A contribuição mais relevante da UCEB era a seriedade com que os acadêmicos, através dela, se relacionavam uns com os outros para buscar através da reflexão e da ação, a melhor maneira de expressar o seu compromisso de fé, como participantes nas reivindicações estudantis. Durante todo aquele período o Shaull era o profeta, o inspirador, o companheiro e (por que não dizer) o patriarca (RAMOS, 1985, p.31).

Porém, nos anos 40 e 50, o protestantismo brasileiro já dava sinais de fragmentação. De um lado, essa nova geração com preocupações ecumênicas, ligada à ULAJE e empolgada com a criação do CMI; de outro lado, um grupo influenciado pelo fundamentalismo e as paraeclesiásticas 3 norte-americanas, denunciava qualquer discurso com preocupações sociais como ameaça comunista. Ainda assim, a primeira Conferência Evangélica Latino-Americana (CELA I), realizada em Buenos Aires em 1949, conseguiu manter certo equilíbrio no cabo-deguerra entre os dois modelos. Os relatórios de CELA I enfatizam o baixo nível de vida e a miséria do povo latino-americano. Porém, apresentam apenas a alternativa de uma religiosidade pessoal comprometida com processos educacionais capazes de erradicar o analfabetismo, o alcoolismo, incentivar a harmonia familiar, o civismo e a saúde dos jovens através da prática de esportes, atividades culturais e ações filantrópicas. Por mais que tivessem consciência dos problemas sociais, isso ainda não representava, para eles, uma crítica ao capitalismo, mas sim um desafio ao progresso. Por isso, a única proposta que lhes parecia viável passava pela conversão individual, a alfabetização, o trabalho honesto e a profissionalização para o mercado de trabalho. Os delegados presentes no CELA I não foram capazes de mobilizar as igrejas porque, conforme Bastian, "não encontraram um discurso e um projeto de evangelização que respondesse aos

\footnotetext{
${ }^{3}$ Paraeclesiásticas são instituições formadas por clérigos e líderes das Igrejas protestantes tradicionais, mas sem compromissos doutrinários ou litúrgicos com as mesmas. Recebem essa designação porque atuam paralelamente às Igrejas, por meio de acampamentos para jovens, publicação de literatura e, eventualmente, educação teológica ou ações sociais. Não estão sujeitas a qualquer fiscalização financeira por parte das igrejas, embora recrutem seus adeptos e colaboradores de dentro das igrejas e insistam em impor às igrejas seus modelos de ação pastoral, litúrgica e suas bases teológicas, geralmente comprometidas com uma matriz pietista, puritana e fundamentalista. No Brasil, as mais influentes paraeclesiásticas foram a Visão Mundial, Vencedores por Cristo, Mocidade para Cristo, Palavra da Vida e, nos anos 80, a VINDE e a ADHONEP.
} 
desafios das massas miseráveis. Neste sentido, mais que o princípio de um protestantismo latino-americano, o CELA I expressou o fim do projeto evangélico liberal para o continente" (BASTIAN, 1990, p. 202).

Nos anos cinquenta do século XX as igrejas protestantes do Brasil estavam às voltas com problemas institucionais decorrentes da emancipação administrativa, assustadas com o crescimento do pentecostalismo e com os primeiros sinais de estagnação do modelo protestante tradicional. Diante da ameaça de tornar-se uma religião minoritária em relação ao pentecostalismo, as igrejas saudaram entusiasticamente o modelo das missões paraeclesiásticas. Mas o problema, conforme Mendonça, apenas se agravou:

As igrejas tradicionais protestantes, a não ser os esforços leigos da escola dominical, parecem ter transferido a obra evangelística para as organizações paraeclesiásticas de caráter conservador... (as consequências são)... conflitos internos provocados por doutrinas religiosas veiculadas pelos agentes e pela mídia e que não são assimiladas pela tradição das igrejas, pelo individualismo incompatível com a vida comunitária e pela ética radicalmente conservadora que envolve características sectárias distanciadoras da realidade social (MENDONÇA, 1992, p. 7 - parêntese meu).

O período que se seguiu ao término da segunda guerra foi marcado pela política norte-americana de conquista dos mercados latino-americanos. Nelson Rockefeller dirigia um comitê encarregado de coordenar os esforços dos Estados Unidos no plano das relações econômicas e culturais com a América Latina. Essa é a época de maior proliferação das chamadas "missões de fé" (hoje são chamados "ministérios") paraeclesiásticas na América Latina. Tais agências são uma importante peça de uma engrenagem com propósitos muito bem definidos. Eram tempos de guerra fria e as paraeclesiásticas se utilizaram desse conflito relacionando qualquer discurso politizado e preocupado com as injustiças sociais como um tentáculo do comunismo. Acrescente-se a isso o fato de a China ter fechado as portas às missões cristãs ocidentais, expulsando centenas de missionários norte-americanos e ingleses em 1950. Todo esse contingente de 
missionários desempregados e apavorados com o comunismo tornou-se mão-deobra barata para o novo campo que se abria: a América Latina. Analisando essa época, Bastian afirma:

A política de boa vizinhança e a criação da Organização de Estados Americanos (OEA) preparou o terreno para assegurar um segundo momento de penetração intensa do capitalismo norte-americano. Esse enorme aumento da presença norte-americana no continente se manifestou religiosamente através da penetração de dezenas de grupos missionários independentes, de teologia fundamentalista e com uma eclesiologia congregacionalista (BASTIAN, 1990, p. 199).

No Brasil, a geração de intelectuais protestantes já estava envelhecida, mas deixara como herança o ideal de um protestantismo arejado e atento à cultura $\mathrm{e}$ aos problemas sociais. As paraeclesiásticas, ao contrário, disseminavam um tipo de protestantismo fechado e sufocante. O choque entre esses modelos fez com que o protestantismo brasileiro chegasse ao final da década de cinquenta bastante dividido. Conforme Bastian,

As igrejas evangélicas históricas, de classe média emergente, recém emancipadas da condução e direção missionárias, estavam sem projeto alternativo e popular para um continente em transformação. Dezenas de denominações e missões de fé, sob liderança norte-americana, e com uma ação missionária psicologizante e modernizante, buscavam uma renovação em uma linha neoevangélica, muito próxima do fundamentalismo. (BASTIAN, 1990, p. 205-206).

Ainda assim, em 1955, por iniciativa de Waldo Cézar e de Shaull, que elaboraram o projeto e a proposta, a CEB aprovou a criação da "Comissão Igreja e Sociedade", que mais tarde transformou-se no Setor de Responsabilidade Social da Igreja (CÉSAR, 1998). Os temas de seus primeiros encontros de estudo foram "A responsabilidade social da Igreja” (1955), "A igreja e as rápidas transformações sociais no Brasil" (1957), "Presença da igreja na evolução da nacionalidade" (1959). A reflexão desenvolvida nesses encontros levou à convocação da Conferência do Nordeste, com o tema "Cristo e o processo revolucionário brasileiro" (Recife, 1962). 
Porém, o início da década de sessenta já prenunciava o surgimento de fortes tensões e atritos entre esse protestantismo influenciado pela teologia liberal e que se pretendia ecumênico e revolucionário e um protestantismo já inoculado pelo vírus do fundamentalismo. $\mathrm{Na} 2^{\mathrm{a}}$ Conferência Evangélica Latino-americana (CELA II), despontaram importantes nomes que se tornaram lideranças representativas do movimento ecumênico e da teologia latino-americana, como José Miguez Bonino e Emílio Castro, formados nos quadros da ULAJE. Do lado oposto, animados com o sucesso das campanhas-cruzadas de Billy Graham pela América Latina, os grupos ligados às paraeclesiásticas convocaram uma consulta sobre evangelização, a CLASE (Consulta Latino-Americana de Evangelização). Os dois encontros foram realizados em Lima (Peru), CELA II em agosto de 1961 e a CLASE em setembro de 1962.

CELA II foi um encontro das Igrejas e Conselhos nacionais. Reuniu 200 delegados de 28 países, representando 42 igrejas nacionais. Foi presidido pelo brasileiro Benjamin Moraes, pastor presbiteriano, que na época era o presidente da CEB. As palestras já apontavam para a interdisciplinaridade entre teologia e ciências sociais. Míguez-Bonino destacava as consequências radicais da encarnação e Emílio Castro alertava para a responsabilidade social das igrejas em um continente subdesenvolvido. Na época, Richard Shaull trabalhava no Brasil, ajudando na formação de uma nova liderança atenta aos problemas sociais. Ele publicara, em 1953, um pequeno livro para subsidiar os debates dos jovens ligados à UCEB. Chamava-se "O Cristianismo e a Revolução Social" (SHAULL, 1953). Apesar do caráter didático e pastoral, o livro de Shaull colocou o termo "revolução" nos lábios daquela geração.

CELA II tem grande importância para o movimento ecumênico na América Latina, pois dela surgiram três organismos que objetivavam aprofundar a relação entre teologia e ciências sociais, produzir material de Educação Cristã de qualidade e incentivar a unidade entre as igrejas. O primeiro foi o ISAL (Igreja e Sociedade 
na América Latina), criado em 1961, formado por jovens protestantes situados no eixo São Paulo-Rio de Janeiro-Montevidéu-Buenos Aires. Esse grupo fundou a revista Cristianismo y Sociedad e a editora Tierra Nueva. A memória do ISAL e de sua importância para a teologia latino-americana pode ser encontrada em escritos de Bittencourt (1988 e 2012) e Góes (1989). O segundo foi CELADEC (Comissão Evangélica Latino-Americana de Educação Cristã), criado em 1962 e, por fim, a UNELAM (União Evangélica Latino-Americana), gestada numa reunião entre os presidentes de seis conselhos nacionais (Argentina, Brasil, Chile, México, Peru e Uruguai) realizada no Rio de Janeiro em 1963. Ali, através da "Declaração do Corcovado", recomendavam a criação de um organismo latino-americano de cooperação evangélica. No ano seguinte (1964), os delegados dos conselhos, reunidos em Montevidéu, organizaram a Comissão Provisória para Unidade Evangélica Latino-Americana, que teve sua Assembleia Constitutiva realizada em Campinas em 1965 e elegeu Emilio Castro para o cargo de secretário-geral (GOODALL, 1970). Desses três organismos, o único que ainda sobrevive é o CELADEC, ligado ao Conselho Latino-Americano de Igrejas (CLAI).

\section{Protestantes ecumênicos e revolucionários}

Os anos sessenta foram fervilhantes, mas também traumáticos, para o protestantismo brasileiro. A geração que sucedeu à dos "liberais" agrupava-se no entorno do Setor de Responsabilidade Social da CEB. A Conferência Mundial sobre Igreja e Sociedade convocada pelo CMI em 1966 com o tema "Os cristãos e a revolução técnica e social de nosso tempo" atestava que o termo "revolução", mais do que slogan, transformara-se, para esse grupo, em categoria teológica. Além disso, a abertura proporcionada pelo Concílio Vaticano II prometia um futuro diferente para as relações entre protestantismo e catolicismo. Rubem Alves, na época, escrevia sua "Teologia da esperança humana" e Gustavo Gutiérrez anunciava uma "Teologia da libertação". O ISAL abastecia a reflexão sobre as relações entre Igreja e Sociedade, ao mesmo tempo em que levantava profundas 
críticas ao conservadorismo e à acomodação das igrejas protestantes. Zwinglio Mota Dias relembra:

A luta dos jovens protestantes de então também se derivou de um conjunto de experiências novas nascidas das aproximações ecumênicas desenvolvidas, principalmente, pelas estruturas organizacionais das juventudes das diferentes denominações. O movimento ecumênico internacional, empenho de aproximação das diferentes vertentes eclesiais do protestantismo já vinha, ainda que lentamente, ganhando corpo entre as igrejas brasileiras. Sua ênfase na cooperação inter-eclesiástica, seu chamamento a um testemunho evangélico comum frente a um mundo fraturado por guerras e discórdias de todo tipo, sua preocupação com a crescente desigualdade econômica e as injustas relações entre as nações sensibilizava profundamente a juventude sempre disposta à novas experiências e impaciente com as visões e formulações desatualizadas de suas instituições eclesiásticas. Quando estas começam a rechaçar essas "novidades", temerosas de perder suas já conquistadas e confortáveis posições de acomodação ao status quo a bandeira do ecumenismo levantada pelos jovens se torna em mais um elemento de conflito no interior das denominações protestantes. No decorrer da história serão esses jovens os principais agentes que vão tornar possível a prática ecumênica entre nós. (DIAS, 2014, p.14).

Mas em 1968 veio o AI-5. O enrijecimento promovido pela ditadura e a suspensão dos direitos políticos abalou toda essa geração, sobretudo porque as lideranças eclesiásticas da época apoiaram o golpe de 1964 e reproduziram internamente processos de repressão que levaram ao fechamento de Seminários, à disciplina de clérigos e leigos, a intervenções autoritárias em movimentos de juventude e outras ações já explicitadas em literatura própria (BRITO, 2014; SOUZA, 2014, PAIXÃO JÚNIOR, 2008). Alguns líderes das igrejas protestantes históricas entregaram seus jovens às hienas. Muitos foram sequestrados e torturados pelos órgãos de repressão, outros foram exilados e muitos (Paulo Wright, Heleny Guariba, Ivan Mota Dias, etc.) simplesmente “desapareceram” nos porões da repressão. É fundamental buscar no relatório da Comissão Nacional da Verdade (apresentado em dezembro de 2014) informações sobre a atuação das igrejas evangélicas durante a ditadura militar, elementos para compreender melhor esse período. Partes dessa história foram registradas por João Dias de Araújo (1982). O movimento ISAL sofreu com a prisão e exílio de seus líderes. A 
Editora Tierra Nueva foi forçada a retirar-se do Uruguai, estabelecendo-se na Argentina, sendo, porém, constantemente vigiada. Na última Assembleia do ISAL (San José, 1975), o organismo foi dissolvido e seus líderes tomaram diferentes rumos. Estrangulada pelo AI-5, a UCEB também não sobreviveu ao golpe, sendo extinta em 1969. Sua correlata entre os grupos neo-evangélicos, a ABU (Aliança Bíblica Universitária), não foi atingida e até hoje é uma pálida versão do que um dia foi a UCEB. Recente estudo recupera a história da ABU e seus conflitos internos, concluindo que, nos anos seguintes ao governo militar, a ABU reforçou sua vocação antiecumênica, fundamentalista e proselitista, interagindo com o ambiente ecumênico apenas como aquário para a busca de potenciais convertidos para as igrejas evangélicas, o "lugar onde se cultiva a verdade" (QUADROS, 2011, p. 103).

O ano de 1969 foi o divisor de águas na América Latina entre protestantes ecumênicos-liberais e protestantes evangélicos-conservadores. A ruptura deu-se durante a CELA III, em Buenos Aires. Era perceptível para muitos a situação de subdesenvolvimento da América Latina, a necessidade de mudanças estruturais e de um compromisso mais efetivo por parte das igrejas no processo de busca de justiça e libertação. O tema da Conferência ("Devedores do mundo") apontava para uma profunda autocrítica do protestantismo, em dívida para com a sociedade. Os estudos prévios abordavam temas como a dívida protestante perante a sociedade rural e urbana, a mulher latino-americana, a juventude e até mesmo para com a comunidade católica. A organização destacou o paradigma da encarnação, utilizado pelo ISAL e reuniu o número mais representativo possível de tendências, incluindo grupos pentecostais. Pela primeira vez no protestantismo latinoamericano, dois observadores católicos romanos foram convidados a participar. Mas a Conferência não esteve isenta de tensões. A Comissão sobre juventude, por exemplo, não chegou a um consenso, apresentando dois relatórios finais à Assembleia. O primeiro, assinado pela maioria, refletia uma linha claramente revolucionária, insinuando inclusive o apoio e engajamento das juventudes protestantes em movimentos clandestinos que combatiam os totalitarismos; o 
segundo, com um menor número de assinaturas, defendia posições nitidamente conservadoras, rejeitando qualquer aproximação com questões políticas. Outro foco de tensão foi o texto de análise de conjuntura distribuído pelo ISAL (1969). Em uma das plenárias, um delegado interpelou Rubem Alves com a seguinte pergunta: "De onde vem a autoridade do ISAL?", ao que Rubem replicou: "é interessante que os fariseus tenham feito a mesma pergunta a Jesus!" (COSTAS, 1976, p. 108). Mais do que uma simples discussão plenária, esse episódio representava a fragmentação evidente no protestantismo latino-americano, já identificada pelo próprio Alves no texto por ele preparado para a Conferência (ALVES, 1970). Em suma, Alves apontava dois caminhos para o protestantismo latino-americano: ser o eixo de um projeto utópico de libertação e subversão da ordem estabelecida ou um instrumento de legitimação ideológica do status quo. Era preciso escolher entre dois caminhos, duas portas, vida ou morte.

A grande maioria dos protestantes conservadores presentes na conferência regressou convencida de que a reunião fora dominada pelos ecumênicos e que o objetivo era manipular as igrejas para a constituição de um poderoso organismo continental semelhante ao CMI. Esse grupo investia suas esperanças no Congresso Latino-Americano de Evangelização (CLADE), marcado para o mesmo ano (novembro de 1969) e alinhado com a Conferência de Evangelização realizada em Berlim (1966) sob os auspícios da Associação Evangelística Billy Graham e da revista Christianity Today. Diversas paraeclesiásticas que atuavam na América Latina e evangelistas latino-americanos se fizeram presentes em Berlim e manifestaram o propósito de formar uma coalizão de forças alternativas ao CMI. Recomendou-se ali a realização urgente de Congressos continentais para tal propósito. O CLADE I foi convocado para Bogotá, no mesmo ano em que se realizaria o CELA III.

O CLADE foi organizado e dirigido por evangelistas norte-americanos e, conforme Costas, "se estabeleceu como uma Conferência rival à CELA III" (COSTAS, 1976, p. 118). Nenhum representante da UNELAM, ISAL, ULAJE ou 
CELADEC foi convidado. O tema escolhido foi "Ação em Cristo para um continente em crise". Mas diferentemente do CELA III, que tocou em problemas estruturais, o CLADE interpretou a crise como um problema espiritual (rebelião ou pecado do ser humano contra Deus). A única vez em que utilizou a palavra "revolução" foi para propor a "revolução espiritual do indivíduo" (COSTAS, 1976, p. 118). Ali começou a se consolidar na América Latina a influência do Departamento de Missiologia do Seminário Fuller, liderado por Donald McGavran, adversário declarado do CMI.

O Comitê organizador do CLADE distribuiu aos participantes um texto de Peter Wagner (também professor do Seminário Fuller), intitulado Teologia Latino-americana: isquierda o evangélica? (WAGNER, 1974), que reconhecia a divisão do campo protestante latino-americano entre ecumênicos e conservadores e esboçava as bases de uma teologia evangélica conservadora. A respeito desse trabalho, Escobar comenta:

Wagner... tinha a intenção de posicionar os evangélicos contra as organizações ecumênicas, as quais descrevia como 'esquerda radical protestante'. Para consegui-lo, fazia uma rápida análise de dez teólogos e algumas instituições. Não era uma análise teológica séria, mas um trabalho jornalístico orientado mais por um critério de rivalidade institucional de que de fundamento teológico. Por isso colocavam na mesma linha pessoas tão diferentes como José Míguez-Bonino ou Justo Gonzáles por um lado, e Richard Chartieer e Richard Shaull, por outro lado (ESCOBAR, 1979, p. 26).

Dentre as iniciativas de um grupo de participantes do CLADE estava a criação de um centro de reflexão capaz de fazer oposição a ISAL. Recebeu o nome de Fraternidade Teológica Latino-americana (FTL). Sua primeira consulta aconteceu em 1970, em Cochabamba (Bolívia), e firmou as bases para uma hermenêutica de oposição aos grupos ecumênicos representados por ISAL. É Escobar ainda que conta:

Neste consenso se havia feito uma crítica frontal a certas formas de fazer teologia que implicavam numa atitude frente ao texto e numa metodologia de trabalho que não fazia justiça ao princípio de autoridade das Escrituras. Tanto Arana como Kirk criticaram o subjetivismo 
fundamentalista, tal como o racionalismo ou existencialismo de outros enfoques e a leitura política que já havia tomado forma nos círculos do movimento Igreja y Sociedad na América Latina (ISAL), antecedente protestante da teologia da libertação (ESCOBAR, 1979, p. 29).

Orlando Costas também reconhece que a FTL pretendia ser "uma alternativa evangélica às correntes representadas pelo movimento Igreja e Sociedade na América Latina" (COSTAS, 1975, p. 42). Por isso os palestrantes tocaram por diversas vezes na crítica ao ISAL e ao seu então presidente, Julio de Santa Ana. Pedro Arana, por exemplo, terminou seu discurso afirmando:

Na ideologia do ISAL, Deus é traduzido como revolução; o povo de Deus como hostes revolucionárias; o propósito de Deus como humanização e a Palavra de Deus como um panfleto revolucionário. Ninguém pode deixar de ver que isto é humanismo marxista (ARANA, 1972, p. 78).

Outro crítico do ISAL era René Padilla, que se tornou secretário-geral da FTL. Em um artigo que antecedeu a consulta de Cochabamba, Padilla qualificou a teologia da revolução de Richard Shaull como "outro evangelho" e declarou que a visão do ISAL a respeito do homem "coincide com a do marxismo, não com a do cristianismo" (PADILLA, 1970, p. 200). Quando, em 1974, realizou-se o Congresso de Lausanne, lá estavam os representantes da FTL: René Padilla e Samuel Escobar. A influência da FTL sobre algumas igrejas protestantes na década de setenta foi considerável, uma vez que se tornou o centro em torno do qual se articulavam alguns líderes. A FTL transmitia a imagem de ser um movimento de vanguarda frente à mediocridade geral que dominava as igrejas latino-americanas da época, já fortemente influenciadas pelo pentecostalismo, mas, ao contrário dos protestantes ligados ao ISAL, seus líderes nunca enfrentaram problemas com os regimes totalitários.

Quanto aos protestantes "revolucionários", poucos encontraram algum apoio por parte de suas igrejas de origem. A Confederação Evangélica do Brasil não 
conseguiu digerir os desdobramentos da Conferência do Nordeste, entrando em crise e, aos poucos, alinhou-se com os movimentos autoritários e repressivos, isolando as lideranças comprometidas com uma elaboração teológica capaz de mobilizar socialmente as igrejas. Os limites deste texto não nos permitem apresentar maiores detalhes dessa história. Depoimentos, entrevistas e análises acadêmicas podem ser encontrados no texto recentemente publicado por Koinonia (DIAS, 2014) como parte do Projeto Marcas da Memória, da Comissão de Anistia do Ministério da Justiça, ou na recente tese de doutorado de Brito (2014). Todos os nomes aqui já citados e outros, como Jether Ramalho, Anivaldo Padilha, Joaquim Beato, João Dias de Oliveira, Zwinglio Mota Dias, Leonildo Silveira Campos, Carlos Cunha e os bispos metodistas Almir dos Santos e Paulo Ayres Mattos, teriam muitas histórias a contar. Alguns depoimentos estão registrados no documentário "Muros e pontes - memórias protestantes na Ditadura", produzido por Koinonia e disponível na internet4. Todos eram protestantes. Alguns, justificadamente, já não mantêm relações com suas igrejas de origem, mas preservam, indelevelmente, o que Tillich chamou "princípio protestante", à espera de que o mesmo ressurja nos caminhos imprevisíveis da história.

\section{0 fim da era protestante ecumênica, liberal e revolucionária no Brasil?}

O atual cenário do protestantismo institucionalizado no Brasil é desanimador para quem viveu ou para quem recebeu a herança de um protestantismo ecumênico, liberal e revolucionário. O protestantismo popular, carismático, reacionário e ideologicamente comprometido com projetos conservadores multiplica-se na mesma proporção em que se subdivide. Quanto ao primeiro modelo, Ricardo Mariano afirma que "o prognóstico parece pouco promissor. Em vez de 'explosão', talvez estejamos assistindo à 'implosão' do protestantismo" (MARIANO 1999, p. 95). Para Mariano, "a mensagem teológica protestante encontra-se em crise e à beira da indigência" (1999, p. 93). O resultado é "prestígio ladeira abaixo" (id, p.94). Daí a sinalização indicada no título de seu

\footnotetext{
${ }^{4}$ Disponível no youtube. Link: https://www.youtube.com/watch?v=ycWCn7qAOo4 (Acesso em 16 abril 2015).
} 
trabalho: "o futuro não será protestante”, que parece responder à indagação de Tillich: estamos vivendo "o fim da era protestante?" (TILLICH, 1992, p.239-254).

De fato, aparentemente, a atual configuração das instituições protestantes no Brasil não nos permite vislumbrar sinais de renovação. Notícias veiculadas pela mídia e pelas redes sociais envergonham os protestantes que se identificam com um projeto diferente do que prevalece atualmente. $\mathrm{Na}$ política brasileira, as sucessivas bancadas evangélicas sempre se unem aos blocos mais conservadores. Programas de rádio e televisão poluem e enuviam os telespectadores com mensagens religiosas que deixam rubras as faces das gerações mais antigas. Pastores incentivam a depredação da arte católica ou afro-brasileira ou excitam a violência explícita contra minorias, especialmente gays, lésbicas e travestis. Além das ostentações e denúncias de sonegações fiscais, há grupos que declaradamente se insurgem contra a Constituição e apregoam uma teocracia evangélica ao estilo Talibã, prometendo tomar os meios de comunicação e as redes sociais e financiar "shows da fé" em lugar das manifestações da cultura popular. A falta de credibilidade do protestantismo é visível para muitos setores da população brasileira.

O inexpressivo crescimento das igrejas que ainda são consideradas como parte do protestantismo histórico no Brasil as fez diminuir os investimentos em educação cristã (formação de leigos), educação teológica (formação de pastores/as e líderes) e no movimento ecumênico. Investir nessas áreas tornou-se preocupação menor, em função dos custos de qualquer processo educacional decente. Educação cristã e educação teológica não trazem resultados imediatos. Além disso, nos anos setenta as paraeclesiásticas de matriz fundamentalista e os evangélicos ligados ao Pacto de Lausanne e à FTL pressionaram as igrejas a se abrir acriticamente ao universo pentecostal, como se ele tivesse tudo a ensinar e nada a aprender. $\mathrm{O}$ complexo de inferioridade e a ânsia por crescimento a qualquer custo fez as lideranças das igrejas protestantes renunciarem à sua herança litúrgica e aderir à 
moda gospel. Afinal, em tempos de escassez, qualquer prato de lentilhas é bemvindo. As paraeclesiásticas, o movimento gospel e a condescendência benevolente e acrítica para com o pentecostalismo trouxeram algum fôlego, mas com prejuízos consideráveis às igrejas protestantes brasileiras. Todas as iniciativas para criar um mínimo de cooperativismo foram tomadas de assalto pelas hordas de pastores interessados em alguma fatia de poder. Os resultados foram as múltiplas divisões dentro das igrejas históricas e a formação de comunidades pouco interessadas em teologia, responsabilidade social ou qualquer assunto que vá além da satisfação de suas necessidades emocionais imediatas.

Nas décadas de sessenta a noventa, as entidades ligadas ao movimento ecumênico ofereceram a muitos protestantes revolucionários uma estrutura mínima a partir da qual era possível refletir sobre as relações entre igreja e sociedade e engajar-se em intervenções práticas capazes de materializar seus ideais. A esses espaços, Bittencourt deu o nome "ilhas de dissidência" (BITTENCOURT, 2014, p. 16). Organismos como o ISER (Instituto de Estudos da Religião), o CEDI (Centro Ecumênico de Documentação e Informação), a CESE (Comissão Ecumênica de Serviço), a CENACORA (Comissão Ecumênica Nacional de Combate ao Racismo), o CESEP (Centro Ecumênico de Evangelização Popular) e outros, além de preservar o ideal de um protestantismo ecumênico e revolucionário e formar novas gerações, sempre foram portos seguros onde se abrigar nos momentos de perseguição política ou eclesiástica. Publicações como a revista Tempo e Presença ajudaram a manter acesos os ânimos dos protestantes liberais. A pequena, mas ativa, "tribo ecumênica" (ABUMANSSUR 1991) ainda conseguiu manter alguma influência, durante certo tempo, em suas igrejas de origem. Muitos se engajaram nos processos de organização do CONIC e CLAI ou em projetos da CESE. A manutenção dessas organizações nunca veio do apoio eclesiástico, mas era viabilizada através de projetos articulados junto a outros setores ecumênicos, principalmente da Europa. A queda do muro de Berlim levou muitas agências financiadoras a direcionar seus recursos para o processo de reorganização da Europa oriental, além de atender a situações emergenciais na 
África. Algumas organizações ecumênicas não conseguiram sobreviver à crise financeira; outras se fundiram, garantindo alguma sobrevida na espera por tempos melhores. O CEDI encerrou suas atividades em 1994, espraiando-se em três novas organizações: Ação Educativa, Instituto Sócio Ambiental e Koinonia - Presença Ecumênica e Serviço. O impacto da "tribo ecumênica" na dinâmica das igrejas diminuiu consideravelmente. Afinal, envolvimento ecumênico também não oferece crescimento; ao contrário, exige desprendimento, cooperação mútua e investimento em ações voltadas para o benefício da sociedade e para políticas sociais de inclusão das minorias, sem esperar retornos imediatos para as igrejas.

Aos poucos, os líderes ecumênicos começaram a perder o pouco espaço que ainda lhes restava nas instâncias administrativas de suas igrejas. Foram substituídos por agentes mais pragmáticos e menos reflexivos, formados em outros ambientes como o CLADE, a FTL e fiéis ao Pacto de Lausanne. A crise financeira, a onda carismática e a febre gospel afastaram as lideranças ecumênicas de muitas instâncias decisórias, diminuindo o número de publicações, eventos e projetos de intervenção social. As novas lideranças que ganharam espaço nas igrejas e na educação teológica, em pouco tempo deixaram claro que a nova face do protestantismo brasileiro renunciava a muitas conquistas do passado. Barrozo, em recente estudo sobre as afinidades dialógicas entre a nova ética das comunidades pentecostais emergentes e o espírito da modernidade religiosa, destaca alguns elementos que caracterizam essas comunidades, dentre eles, "o caráter exclusivamente espiritual dos propósitos religiosos dos aderentes. Para essas comunidades, a religião não mobiliza necessariamente para engajamentos de ordem utópica, mas potencializa experiências emotivas profundas" (BARROZO, 2014, p. 70). Outro pesquisador da nova geração reconhece que, no Brasil, "a identidade evangélica foi inelutavelmente conquistada pelo neopentecostalismo." (BAPTISTA, 2013, p. 98)

Em 2006 a Igreja Metodista do Brasil, berço de muitos protestantes pluralistas e revolucionários, decidiu, em seu $18^{\circ}$ Concílio Geral, por retirar-se do 
CONIC, CESE e de outras entidades ecumênicas. Mais recentemente (julho de 2015), a Igreja Presbiteriana Independente, outro berço de protestantes liberais e revolucionários, decidiu, em sua $9^{\text {a }}$ Assembleia Geral, romper históricas relações com a PCUSA (Presbiterian Church of USA). Dentre outros motivos, estava a abertura dos presbiterianos daquele país ao reconhecimento dos direitos de pessoas homoafetivas.

Porém, tais retrocessos não foram capazes de silenciar o princípio protestante. Alguns grupos articulam resistência através de redes sociais. É o caso da Rede Metodista Confessante 5 e da já insinuada articulação no Facebook de presbiterianos independentes inconformados e descontentes com os retrocessos da denominação. A tribo ecumênica, teimosamente, ainda bate seus tambores e envia sutis sinais de fumaça, esperando por interlocutores comprometidos com um cristianismo mais plural, menos igrejeiro e mais empenhado nas lutas sociais e na defesa dos direitos das minorias. O FEBRASIL (Fórum Ecumênico Brasil), a Koinonia e a REJU (Rede Ecumênica de Juventude) representam novas "ilhas de dissidência" que reúnem pessoas esperançosas de que o princípio protestante volte a agir nas instituições protestantes. Conforme Bittencourt,

No cenário atual os integrantes dessas "ilhas" persistem no empenho de fundamentar e justificar suas ações pastorais e políticas utilizando-se como o fizeram desde sempre - do ecumenismo como seu principal instrumento de luta. Na proporção em que as denominações clássicas, em todas as partes do mundo vão experimentando um processo acelerado de extinção, o que restam são as práticas e os discursos dessas ilhas que teimam, apesar de toda a precariedade e de todas as vicissitudes, em cultivar o "espírito protestante". (BITTENCOURT, 2014, p. 17).

\section{Considerações finais para manter a esperança}

Antonio Gouvêa Mendonça iniciou um de seus últimos textos falando sobre o ofício fúnebre de outro sociólogo protestante - o francês Roger Bastide, um dos pioneiros da Sociologia da Religião no Brasil. Em seus tempos de USP, Bastide se interessou pelas religiões de matriz africana, viajando várias vezes para pesquisas

\footnotetext{
${ }^{5}$ Ver o site http://metodistaconfessante.blogspot.com.br
} 
de campo, ao mesmo tempo em que frequentava, esporadicamente, a $1^{\text {a }}$ Igreja Presbiteriana Independente de São Paulo e a Igreja Presbiteriana Unida, em Campos Elíseos. O funeral de Bastide, em 1974, foi oficiado pelo pastor Raymond Leenhardt, do Instituto de Línguas Orientais da Sorbonne, mas Mendonça chama a atenção para o fato de também ter sido acompanhado por "tambores religiosos, alternando toques brasileiros e africanos, reunindo assim numa só homenagem as religiões que sem dúvida formavam o pano de fundo de todo o pensamento de Roger Bastide, homem e sociólogo: o protestantismo e os cultos afro-brasileiros” (CERU, apud MENDONÇA, 2004). Mendonça discorre sobre esse aparente paradoxo e reconhece que Bastide se alinhava, por um lado, aos teólogos liberais do século XIX, mas também aos místicos que, embora sem romper com a igreja, viveram às suas margens, e escreve:

É extraordinário que um protestante de tradição calvinista, formado, portanto, no rigor dogmático e ético da Reforma franco-suíça, com seu culto extremamente intelectual e, diríamos mesmo, desencantado e quase secular, beirando o profano no sentido puramente técnico deste termo, tivesse uma cerimônia fúnebre de tal natureza. Pois que os tambores afros não representavam outra coisa senão o mistério de cultos em que os deuses se mostram de maneira diferente, não enquadrados em dogmas ou éticas institucionais (MENDONÇA, 2009, p. 29).

De modo semelhante, as duas gerações aqui citadas, de acordo com as possibilidades e limites de sua época (e algumas vezes para muito além dessas mesmas possibilidades e limites), uniram de um modo bastante peculiar a intensidade de sua experiência religiosa e mística a diferentes compromissos: a primeira, entre os anos 30 e 50, sonhava com um protestantismo intelectualizado, comprometido com um Brasil moderno e, por isso, defendia um civismo generoso mas, por vezes, ingênuo; a segunda, entre os anos 50 e 70, aprofundou esse compromisso, voltando-se à defesa dos pobres e excluídos. Agostinho diria que, em meio à cidade dos homens, ambas foram inflamadas pelo ardor do Eterno e pelo amor à cidade de Deus, e compreenderam que "dois amores fundaram duas cidades: o amor próprio até ao desprezo de Deus, a terrena; o amor a Deus 
até ao desprezo de si próprio, a celestial” (AGOSTINHO, 2005, p. 28). Aprofundando essa metáfora no De Genesi ad litteram (Livro 11, capítulo XV), Agostinho acrescenta:

Estes dois amores (...) um social, o outro privado; um que olha para o bem comum, o outro que submete o comum ao seu poder (...) um é tranqüilo, e o outro turbulento; um deseja para o próximo o que quer para si, e o outro quer submeter o próximo a si (...) ; esses dois amores, de que já se imbuíam os anjos, um nos bons, e o outro nos maus, esses dois amores erigiram duas cidades por entre os homens (AGOSTINHO, 2005, p. 402)

Permanece aberta uma questão que merece maior aprofundamento - se esse tipo de protestantismo, sem renunciar a seus ideais, preserva uma reserva dialogal de comunicação com a nova classe média brasileira, sobretudo com os jovens universitários já totalmente influenciados por outro modelo. Para tanto, será necessário levar em consideração os anseios e buscas espirituais dessa nova geração em uma sociedade cada vez mais midiática e propensa a surtos emocionais, e as respostas que a espiritualidade e a mística protestante podem oferecer às necessidades religiosas desses grupos.

Iniciei este texto com as palavras de Waldo Cézar lamentando o cansaço com um cotidiano difícil e imaginando "uma Igreja que poderia ter sido e não foi”. (CÉSAR, 2014, p. 98). Esse desconforto permanece na pergunta que muitos ainda fazem: onde estão, atualmente, os protestantes que não hesitaram em entregar seus corpos - até mesmo em prejuízo de suas vidas conjugais e de suas famílias como "sacrifício vivo e santo" em prol de nobres ideais? Alguns já faleceram, mas a memória de seu testemunho não pode ser esquecida. Outros estão conosco, dispostos a participar nos processos de formação das novas gerações. As novas gerações protestantes muito se beneficiarão em saber que, no passado, jovens como eles, que entoaram hinos como "Ao Deus de Abrão louvai”, "Vigiar e orar”, "Deus cuidará de Ti”, "Eu creio, Senhor, na divina promessa”, também escreveram com sangue e sofrimento, literalmente, páginas inapagáveis na história da 
sociedade brasileira. Alguns, talvez, poderão manter acesa a chama de um protestantismo liberal, pluralista, ecumênico e socialmente relevante.

\section{REFERÊNCIAS}

ABUMANSSUR, Edin. A tribo ecumênica - um estudo do ecumenismo no Brasil nos anos 60 e 70. 1991. Dissertação (Mestrado em Ciências Sociais)- Pontifícia Universidade Católica de São Paulo, São Paulo, 1991.

AGOSTINHO, Santo. A cidade de Deus, (trad. Oscar Paes Leme) Bragança Paulista: Editora Universitária São Francisco, 2005.

AGOSTINHO, Santo. Comentário ao Gênesis, (trad. Agustinho Belmonte), São Paulo: Paulus, 2005.

ALVES, Rubem. Protestantismo e Repressão. São Paulo: Ática, 1979.

ALVES, Rubem. Dogmatismo e tolerância. São Paulo: Paulinas, 1982.

ALVES, Rubem. Función ideológica y posibilidades utópicas del protestantismo

Latino-americano. In: VV.AA. De la iglesia y la sociedade. Montevidéu: Tierra Nueva, 1971, p.1-21.

ARANA, Pedro. La revelación de Dios y la teologia em Latino-america. In: SAVAGE, P. (org.). El debate contemporâneo sobre la Biblia. Barcelona: Ediciones Evangelicas Europeas, 1972.

ARAÚJO, João Dias de. Inquisiçãa sem fogueiras - vinte anos de história da Igreja Presbiteriana do Brasil (1954-1974). Rio de Janeiro: ISER, 1982.

BAPTISTA Saulo. Fundamentalismo e identidades no campo evangélico brasileiro. In: CONCEIÇÃO, Douglas; MORAES JR, Manoel. Religióes no Brasil - ciência, cultura, política e literatura. São Paulo: Fonte Editorial, 2013.

BARRETO JR, Raimundo. O Movimento Ecumênico e o Surgimento da Responsabilidade Social no Protestantismo Brasileiro. Numen: revista de estudos e pesquisa da religião, Juiz de Fora, v. 13, n. 1 - 2, p. 273-323, 2010. 
BARROZO, Victor Breno. Pentecostalismo à la modernité: afinidades dialógicas entre a nova ética das comunidades pentecostais emergentes e o espírito da modernidade religiosa. In: OLIVEIRA, David Mesquiati (org.). Pentecostalismos em diálogo. São Paulo: Fonte Editoria/RELEP, 2014.

BASTIAN, Jean-Pierre. Historia del Protestantismo en America Latina. México, CUPSA: 1990.

BERGER, Peter. Are the evangelicals winning the world? The American Interest (3 julho 2015). Disponível em:< http://www.the-american-interest.com/2015/o6/o3/areevangelicals-winning-the-world/> . Acesso em: o7 de julho de 2015 .

BITTENCOURT Filho, José. Por uma eclesiologia militante: ISAL como nascedouro de uma nova eclesiologia para a América Latina. 1988. Dissertação (Mestrado em Ciências da Religião). Instituto Metodista de Ensino Superior, São Bernardo do Campo, 1988.

BITTENCOURT Filho, José. ISAL e seu contexto - um ensaio. In: ROSA, Wanderley e ADRIANO F, José (org.). Cristo e o processo revolucionário brasileiro - A Conferência do Nordeste 50 anos depois (1962-2012). Rio de Janeiro: Mauad, 2012.

BRITO, André Souza. Cristianismo ateu - o movimento ecumênico nas malhas da repressão militar do Brasil. 1964-1985. 2014, 414f. Tese (Doutorado em História Social)Universidade Federal Fluminense, Rio de Janeiro, 2014.

CAMARGO, Cândido P. F. Católicos, protestantes e espíritas. Petrópolis: Vozes, 1973 .

CERU. Cadernos do Ceru-Centro de Estudos Rurais e Urbanos, n. 10, nov. 1977 (número dedicado a Roger Bastide).

CÉSAR, Waldo. Church and Society - Or Society and Church?. In: LEWIS, Nantawan B. (ed.). Revolution of Spirit: Ecumenical Theology in Global Context. Essays in Honor of Richard Shaull. Grand Rapids: W. B. Eerdmans Publishing Co., 1998, p. 133-148.

CÉSAR, Waldo. O itinerário de vida de um coração ecumênico. In: DIAS, Zwinglio Mota (org). Memórias ecumênicas protestantes - Os protestantes e a Ditadura: colaboração e resistência. Rio de Janeiro: KOINONIA Presença Ecumênica e Serviço, 2014 .

COPPE, Moisés Abdon. A responsabilidade social e política dos cristãos: história e memória da União Cristã de Estudantes do Brasil (UCEB) entre as décadas de 1920 e 1960. 2009, 161f. Dissertação (Mestrado em Ciências da Religião)- Universidade Federal de Juiz de Fora, Juiz de Fora, MG, 2009.

COSTAS, Orlando. Theology of the crossroads in contemporary Latin America. Amsterdam: Rodopi, 1976.

DIAS, Agemir de Carvalho. O movimento ecumênico no Brasil contemporâneo: 19802000. Estudos Teológicos, São Leopoldo v. 54, n. 1, p.140-152, jan./jun 2014. 
DIAS, Zwinglio Mota (org.). Memórias ecumênicas protestantes - Os protestantes e a Ditadura: colaboração e resistência. Rio de Janeiro: KOINONIA Presença Ecumênica e Serviço, 2014. Disponível em:

<http://koinonia.org.br/protestantes/downloads/PDF_Memorias\%20Protestantes.pdf>. Acesso em: 13 julho 2015.

ESCOBAR, Samuel. Del CLADE I al CLADE II: evangélicos em busca uma evangelización contextual. Pastoralia, San Jose, v.2, n.3, p. 22-30, sep.1979.

FERREIRA, J. A. Profeta da unidade: Erasmo Braga - uma vida a descoberto. Petrópolis: Vozes, 1975.

GONÇALVES, Carlos Barros. Usos e abusos de uma vida: a biografia de Erasmo Braga e o protestantismo brasileiro nas décadas de 1950 a 1970. Anais do XXVII Simpósio Nacional de História - ANPUH (Natal, RN - julho de 2013). Disponível em:<http://www.snh2013.anpuh.org/resources/anais/27/1364947101_ARQUIVO_ANPU H-2013-CarlosBarrosGoncalves.pdf $>$.

GÓES, Paulo de. Do Individualismo ao Compromisso Social. A contribuição da Confederação Evangélica do Brasil para a articulação de uma ética social cristã. 1989. Dissertação (Mestrado em Ciências da Religião)- Instituto Metodista de Ensino, São Bernardo do Campo, 1989.

GOODALL, Norman. El Movimiento Ecumenico (apêndice II: "El Ecumenismo em America Latina”, por Marcelo Peres Rivas). Buenos Aires: La Aurora, 1970.

ISAL. Sobre la vida de las iglesias y el movimiento ecuménico en América Latina: una posición de ISAL. Montevidéu: ISAL, 1969.

LIMA, Éber Ferreira S. Entre a sacristia e o laboratório: os intelectuais protestantes brasileiros e a produção da cultura (1903-1942). 2008, 195p. Tese (Doutorado em História)- UNESP/Faculdade de Ciências e Letras, Assis, 2008. Disponível em: <http://repositorio.unesp.br/bitstream/handle/11449/103171/lima_efs_dr_assis.pdf?seq uence $=1>$ Acesso em: 6 junho 2015 .

MARASCHIN, Jaci. Igreja a gente vive - uma introdução ao pensamento de Frederick Denison Maurice. Porto Alegre: Igreja Episcopal Anglicana do Brasil, 1991.

MARIANO, Ricardo. O futuro não será protestante. Ciencias Sociales y Religión/Ciências Sociais e Religião, Porto Alegre, v. 1, n. 1, p. 89-114, set. 1999.

MATOS, Alderi Sousa de. Erasmo Braga, o protestantismo e a sociedade brasileira. São Paulo: Editora Cultura Cristã, 2008.

MENDONÇA, Antonio Gouvêa. O Celeste Porvir - a inserção do Protestantismo no Brasil. São Paulo: Paulinas, 1984. 
MENDONÇA, Antonio Gouvêa. Histórico das práticas evangelísticas até a teologia da libertação. Contexto Pastoral n. 9. Campinas: CEBEP/CEDI, jul.-agos., 1992.

MENDONÇA, Antonio Gouvêa. A experiência religiosa e a institucionalização da religião. Estudos Avançados, São Paulo, v.18, n.52, p. 29-46, 2004.

NIEBUHR, H. Richard. Cristo e Cultura. (trad. Jovelino Pereira Ramos). Rio de Janeiro: Editora Paz e Terra, 1967.

PAIXÃO JÚNIOR, Valdir Gonzales. Poder e memória: o autoritarismo na Igreja Presbiteriana do Brasil no período da ditadura militar. (Tese de doutorado em sociologia). Araraquara, Universidade Estadual Paulista, 2008.

PADILLA, René. Mensaje bíblico y revolución. Certeza, Buenos Aires, n. 39, eneromarzo de 1970.

QUADROS, Eduardo Gusmão de. Evangélicos e mundo estudantil: uma história da Aliança Bíblica Universitária no Brasil (1957-1981). Rio de Janeiro: Novos Diálogos Editora, 2011.

RAMOS, Jovelino P. Você Não Conhece o Shaull? In: SHAULL, Richard et al. De dentro do furacão: Richard Shaull e os primórdios da Teologia da Libertação. São Paulo: Editora Sagarana; CEDI/CLAI, 1985, p. 25-32.

SHAULL, Richard. O cristianismo e a revolução social. São Paulo: UCEB, 1953.

SOUZA, Silas Luiz. Protestantismo e Ditadura - os presbiterianos e o governo militar no Brasil (1964-1985). São Paulo9: Fonte Editorial, 2014.

STELLA, Jorge Bertolaso. A morte de Pericle Ducati e a etruscologia. Revista de História, v. 1, n.3, 1950, p. 297-299, 1950.

STELLA, Jorge Bertolaso. L’Afrique Poliglotte. Revista de História, v. 2, n.6, 1951, p. 442-444, 1951.

STELLA, Jorge Bertolaso. O Rig-Veda. São Paulo: Imprensa Metodista, 1958.

STELLA, Jorge Bertolaso. A oração na história das religiões. São Paulo: Imprensa Metodista, 1968.

STELLA, Jorge Bertolaso. As religiões da Índia. São Paulo: Imprensa Metodista, 1971.

STELLA, Jorge Bertolaso. Estudos Hindus. São Paulo: Imprensa Metodista, 1978.

TILLICH, Paul. The end of the protestant era?. The Protestant Era. Chicago: University of Chicago, 1948. Edição brasileira: MARASCHIN, Jaci (trad.). A Era Protestante. São Paulo: Ciências da Religião, 1992, 332p. 
ULAJE. Congresso Latino-Americano de Juventudes Evangélicas -Com Cristo um mundo nuevo. Argentina: Comisión Central Provisional de la ULAJE, 1942.

WAGNER, Peter (ed.). A catalog of the C. Peter Wagner Collection of materials on Latin American Theology of Liberation. Pasadena: Fuller Evangelical Associations, 1974. 